\title{
LA UNIVERSALIDAD DE LA VIDA ES SUEÑO A LA LUZ DE LA TRIPLE MIMESIS DE PAUL RICOEUR
}

\author{
Maria Turu Tarré \\ Humanitats i Ciències de l'Educació \\ Universitat Abat Oliba CEU \\ Bellesguard 30 \\ 08022 Barcelona. España \\ mturut@uao.es
}

[Anuario calderoniano (ISSN: 1888-8046), 7, 2014, pp. 255-281]

La importancia de La vida es sueño dentro de la producción de Calderón y en el panorama del teatro barroco es el más claro testimonio de su originalidad, de la especial peculiaridad que lo convierte en universal. Sin embargo, puede resultar interesante preguntarse acerca de la universalidad de esta obra única en cuanto concreción de una fórmula común: la definición de tragedia en la Poética de Aristóteles. Se trataría, por tanto, de examinar La vida es sueño a la luz de la teoría aristotélica acerca de la naturaleza y fin de la poesía trágica, tomando de la Poética los conceptos de mimesis y catarsis como factores de universalidad en la obra. Así, entendiendo que «la imitación de una acción $[\ldots]$ que mediante compasión y temor lleva[n] a cabo la pur- 
gación de tales afecciones» (1449b28) ${ }^{1}$ es lo propio de una obra que habla de lo universal ${ }^{2}$, se expondrá de qué modo aparecen en La vida es sueño estos principios.

\section{Presupuestos teóricos}

Cabe recordar brevemente el papel que asigna Aristóteles a ambos conceptos en su Poética. Respecto a la mimesis, constituye el origen (1448b20) y el fundamento mismo de la poesía ${ }^{3}$ —entendida como proceso creativo- - y aparece desarrollada en la distinción según los medios, el objeto y el modo con que caracteriza a la tragedia (1447a1448a). En cuanto a la catarsis, es el fin del arte poético ${ }^{4}$, el efecto que debe provocar la contemplación o lectura de la obra en el receptor y que debe surgir necesariamente de la estructura de la trama (1453b). En qué consisten una y otra queda condensado en la conocida definición arriba mencionada, que se podría reformular aquí como síntesis de la hipótesis de este estudio: «La vida es sueño es la representación del anhelo, abuso y reconquista de la libertad [...], que suscita temor y compasión y mediante éstos muestra que la verdadera libertad se adquiere mediante la virtud». Se plantea así el núcleo de las dos cuestiones en juego: mimesis de la libertad y catarsis como enseñanza moral.

El desarrollo de estos dos planteamientos requiere aún una precisión teórica previa. A modo de síntesis y actualización de estos conceptos, evocamos aquí la lectura que Paul Ricoeur hace de la Poética de Aristóteles en su obra Tiempo y narración ${ }^{5}$. En ella, Ricoeur retoma el concepto de mimesis praxeos insistiendo en su doble pertenencia al mundo real o ético y al mundo de la ficción o poético ${ }^{6}$, y expone su tesis de la "triple mimesis», que abarca tres momentos de la composi-

${ }^{1}$ Todas las citas están tomadas de la edición de García Yebra, 1974.

2 Aristóteles contrapone la poesía a la historia afirmando que «la poesía dice más bien lo general, y la historia lo particular» (1451b7).

3 «La imitación, para Aristóteles, constituye la naturaleza íntima de la poesía y es causa de su origen» (Sánchez Palencia, 1996, p.131).

4 «El fin de la imitación trágica es una acción íntegra que inspira temor y compasión» (Sánchez Palencia, 1996, p. 141).

${ }^{5}$ Publicada en 1985 con el título Temps et récit, editada en español por A. Neira en 1995.

${ }^{6}$ Ricoeur, 1995, p. 103. 
ción poética: mimesis I se refiere al 'antes', a la prefiguración de la trama y a la comprensión previa del obrar humano, de los rasgos que caracterizan al mundo de la acción, "de sus estructuras inteligibles, de sus recursos simbólicos y de su carácter temporal» ${ }^{7}$; mimesis II se refiere a la configuración de la trama y constituye la función-base en cuanto realiza «una función de integración y [...] de mediación», puesto que «media entre acontecimientos o incidentes individuales y una historia tomada como un todo", de tal modo que "transforma estos acontecimientos o incidentes en una historia» ${ }^{8}$; mimesis III se refiere al 'después', a la refiguración de la obra a través de la lectura que completa «la transición entre mimesis II y mimesis III [...] y concluye el acto configurante»" ${ }^{9}$ así pues, "marca la intersección del mundo del texto y del mundo del oyente o del lector» ${ }^{10}$, aunque el autor señala que sólo en parte se refiere a la catarsis ${ }^{11}$.

Este triple desarrollo del concepto aristotélico que propone Ricoeur servirá como herramienta de análisis de las nociones de mimesis y catarsis en La vida es sueño. Tal aproximación teórica invita a examinar desde una triple perspectiva la representación de la libertad que constituye el tema central de la obra: las fuentes del tópico, el tratamiento que le da el autor y el potencial comunicativo de la obra.

\section{Mimesis I y mimesis II}

El punto de partida es mimesis II, el texto literario de La vida es sueño, cuya configuración descansa sobre dos pilares temáticos: la libertad y el sueño. Estos dos elementos remiten a la denominada mimesis I, en cuanto refieren el análisis a los antecedentes de la obra. Además de las fuentes de las que bebe el drama de Calderón ${ }^{12}$, cabe destacar

7 Ricoeur, 1995, p. 116.

${ }^{8}$ Ricoeur, 1995, p. 131.

${ }^{9}$ Ricoeur, 1995, p. 147.

${ }^{10}$ Ricoeur, 1995, p. 140.

11 «Las alusiones que hace la Poética al placer obtenido [...] al experimentar temor y compasión [...] constituyen sólo el esbozo de la teoría de mimesis III» (Ricoeur, 1995, p. 111). Ricoeur completa aquí su análisis con referencias a la teoría de la lectura y la estética de la recepción (p. 148).

12 Martín de Riquer, en su edición de La vida es sueño, resume la génesis de la obra a partir de estos dos elementos: por un lado, señala que «el motivo del príncipe 
sobre todo el contexto histórico y cultural en que se inscribe La vida es sueño, y dentro de él especialmente una circunstancia particular que acota el concepto de libertad: la polémica teológica en torno al libre albedrío. Considerando la fecha de composición de 1635, el momento vital del autor y el ambiente que lo circunda ${ }^{13}$ apuntan a un sólido armazón doctrinal, revestido de virtuosismo barroco. La cuestión del libre albedrío había sido reafirmada por el Concilio de Trento en $1547^{14}$ frente al siervo arbitrio postulado por la Reforma. Es cierto que, aparentemente, Calderón no concibe su obra en términos teológicos - de ahí que la crítica proponga «una lectura laica»" ${ }^{15}$. A pesar de ello, creemos que es lícito establecer una cierta correspondencia entre la trama argumental de La vida es sueño y la controversia religiosa del momento ${ }^{16}$. De este modo, mimesis I enlaza con mimesis II, pues

encerrado por designios astrológicos, procedente de la leyenda de Buda se cristianizó gracias a la versión que se conocía como obra de San Juan Damasceno y que dio lugar al Barlaán y Josafat de Lope de Vega». Por otro lado, indica que «el tema del borracho al que se hace vivir unas horas como un príncipe, procedente de El Conde Lucanor de don Juan Manuel, fue atribuido por Luis Vives a Felipe el Bueno de Flandes y dio lugar a ciertas escenas de El Natural desdichado de Agustín de Rojas» (p. 24).

13 «el espíritu que mueve el Barroco [...] en España se extrema por evidentes razones históricas - hondura de la tradición teológica en crisis frente a la heterodoxia» (Riquer y Valverde, 2010, p. 771).

${ }^{14}$ En la sesión VI (13 de enero de 1547), Can. 4 y 5: «1554 Can. 4. Si alguno dijere que el libre albedrío del hombre, movido y excitado por Dios, no coopera en nada asintiendo a Dios que le excita y llama para que se disponga y prepare para obtener la gracia de la justificación, y que no puede disentir, si quiere, sino que, como un ser inánime, nada absolutamente hace y se comporta de modo meramente pasivo, sea anatema. 1555 Can. 5. Si alguno dijere que el libre albedrío del hombre se perdió y extinguió después del pecado de Adán, o que es cosa de sólo título o más bien título sin cosa, invención, en fin, introducida por Satanás en la Iglesia, sea anatema» (Denzinger, Enchiridion symbolorum).

15 «Una lectura laica es igualmente posible» (Antonucci, 2008, p. 30). Antonucci propone una lectura «sin esos prejuicios que muchas veces constituyen un lastre para la interpretación enriquecedora del teatro áureo: es decir, para el receptor que no decida ver en La vida es sueño la plasmación sin residuos de esa visión del mundo trascendente, inmovilista, reaccionaria que sería la típica del Barroco español y de una cultura cuyo vértice eran el trono y el altar» (p. 38).

16 «El escenario se presta a la controversia de auxiliis: la polémica teológica entre los jesuitas (que valoraban la inteligencia, voluntad y libre albedrío del individuo con el apoyo eficaz de la gracia divina que, de ese modo, no le impide la libertad de elegir), y los dominicos (que, por oposición, se mostraban defensores de la total omni- 
la representación de la libertad es prefigurada por las cuestiones teológicas que se reelaboran literariamente.

El análisis de mimesis I, por tanto, proporciona un anclaje teórico a la identificación de ciertos presupuestos teológicos - tales como la predestinación y el libre albedrío - en la trama de la obra. Además, este mismo concepto ofrece una semántica de la acción, una estructura dramática reconocible en la que se insertan las relaciones de conflicto y conversión. Según esto puede afirmarse que la predestinación es la causa del conflicto; y la falta de libertad, su efecto; a través de la virtud conquista el príncipe la libertad: dicho de otro modo, se salva por las obras. Así pues, la construcción de la trama parece plantear en primer lugar la objeción protestante del siervo albedrío para ofrecer después la respuesta católica del libre albedrío. Se examinará a continuación cómo se articulan estas dos líneas temáticas subyacentes de mimesis I en la configuración de mimesis II. Cabe señalar que la argumentación que sigue primará la dimensión simbólica sobre el aspecto lingüístico ${ }^{17}$ en el análisis de las actuaciones de los personajes.

\section{LA PREDESTINACIÓN PROTESTANTE Y EL SIERVO ALBEDRÍO}

El factor desencadenante del drama es la confianza ciega de Basilio en el cumplimiento del hado, que lo lleva a privar de libertad y de educación a su hijo. De algún modo, podría considerarse que el padre de Segismundo adopta en la obra los presupuestos de Lutero, al menos en cuanto a la visión determinista del destino de su hijo. Lutero funda su doctrina de la predestinación en la voluntad inmutable de Dios, que sin permitir la más mínima contingencia hace imposible el libre albedrío humano ${ }^{18}$. Consecuencia de esta doctrina es la doble predestinación, que ordena a unos para la vida eterna, y a otros para con-

potencia y justicia divinas). Calderón, formado en los jesuitas, sigue, naturalmente, esta tendencia optimista que permite al hombre, a través de una peripecia o drama, enfrentarse al orden negativo del hado» (Rodríguez Cuadros, 2007).

17 Remitimos, pese a lo polémico de sus opiniones probablemente ya superadas, a las observaciones de Menéndez Pelayo en «Calderón y su teatro», 1941.

18 «La presciencia de Dios no es tal que deje juego libre a la contingencia, sino que él prevé, se propone y hace todas las cosas con voluntad inmutable, eterna e infalible. Mediante este rayo fulminante es echado por tierra y totalmente aniquilado el libre albedrío». Lutero, De servo arbitrio, cap. IV. 
denación perpetua ${ }^{19}$. En cuanto a Basilio, pese a que no se refiere directamente a una Providencia divina, sí aparece en su razonamiento un designio astrológico que determina la vida de los hombres impidiendo toda contingencia. Como astrólogo, Basilio lee los signos de los cielos y afirma la predestinación de Segismundo condenándolo antes de su nacimiento:

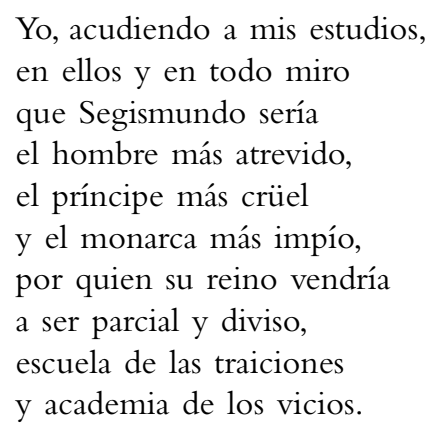

$(\text { vv. } 708-717)^{20}$

El encierro que decreta el rey como consecuencia de su propia predicción niega doblemente la libertad del príncipe: no sólo porque le impide la libertad fisica, sino especialmente porque lo priva de educación. La prisión impide a Segismundo moverse libremente, pero sobre todo, aunque de forma menos percetible, crecer moralmente. En él se hace patente que, si las cadenas físicas reducen al ser humano a una postración inhumana, el encadenamiento moral lo rebaja a una situación de bestialidad. Además, esta segunda carencia es especialmente grave por cuanto se trata de un futuro rey. En efecto, la persona destinada a mandar sobre otras debe poseer en mayor grado las virtudes de justicia, fortaleza y templanza, y aún más la de prudencia, particularmente la prudencia política ordenada al bien común de la

19 «Llamamos predestinación al eterno decreto de Dios, por el que ha determinado lo que quiere hacer de cada uno de los hombres. Porque Él no los crea a todos con la misma condición, sino que ordena a unos para la vida eterna, y a otros para condenación perpetua. Por tanto, según el fin para el cual el hombre es creado, decimos que está predestinado a vida o a muerte». Calvino, Institución de la religión cristiana, vol. III, cap. XXI, art. 5.

${ }^{20}$ Todas las citas de La vida es sueño utilizadas en este trabajo proceden de la edición de Fausta Antonucci, 2008. 
nación ${ }^{21}$. El príncipe heredero de Polonia carece de todas estas virtudes, puesto que no ha sido educado en ellas.

Pero también la decisión de su padre de devolverlo súbitamente a su condición real supone un nuevo impedimento para adquirir aquellas virtudes. La liberación sume a Segismundo en una confusión que más bien oscurece su razón que la aclara. La nueva turbación no viene ciertamente a ayudarle a adquirir aquel estado de virtud necesario para gobernarse a sí mismo y a los demás rectamente. El príncipe parte de dos carencias: virtud y verdad, puesto que no ha sido educado en el encierro y ha sido engañado en la liberación. La consecuencia de este tratamiento aparece en su comportamiento, que viene a confirmar los pronósticos del rey.

Tal como esperaba Basilio de la condición natural de su hijo, a la perplejidad de despertar en un ambiente desconocido sigue inmediatamente la experiencia súbita de una libertad identificada ahora como poder ilimitado:

Pero sea lo que fuere, ¿quién me mete en discurrir?

Dejarme quiero servir, $\mathrm{y}$ venga lo que viniere.

(vv. 1244-1247)

Elevado de pronto a una situación de superioridad en su condición de príncipe heredero, a la ausencia de límites fisicos sumará la ausencia de límites morales:

$$
\begin{aligned}
& \text { ¿qué tengo más que saber, } \\
& \text { después de saber quién soy, } \\
& \text { para mostrar desde hoy } \\
& \text { mi soberbia y mi poder? }
\end{aligned}
$$

(vv. 1296-1299)

Según el lema que rige su actuación:

${ }^{21}$ Ver Aquino, Summa Theologiae, II-II, q. 47, a. 11. 
Nada me parece justo

en siendo contra mi gusto,

(vv. 1417-1418)

el principio rector de todos sus actos es su voluntad movida por la pasión que lo domine en cada momento: sea ésta la ira - que lo mueve a arrojar por la ventana a un criado impertinente- o la lujuria - que lo mueve a ofender a Rosaura- Segismundo se comporta, por tanto, como un incontinente, en tanto que decide entregarse a los placeres como una ostentación de su $\operatorname{poder}^{22}$. De este modo, intimida a Rosaura mostrando mayor violencia en la actitud arrogante que en los mismo gestos:

Sólo por ver si puedo

harás que pierda a tu hermosura el miedo, que soy muy inclinado a vencer lo imposible. Hoy he arrojado dese balcón a un hombre que decía que hacerse no podía; y así, por ver si puedo, cosa es llana que arrojaré tu honor por la ventana.

(vv. 1638-1645)

De este modo, la actuación del heredero de Polonia confirma el vaticinio y las acusaciones de los demás personajes caen sobre él, sentenciado por el cumplimiento del hado. Sólo Clotaldo, entre todas las voces condenatorias, contempla la posibilidad de aplacar su fiereza, partiendo del presupuesto de

que vencerá[s] las estrellas, porque es posible vencellas

a un magnánimo varón.

(vv. 1285-1287)

22 «El que se entrega al exceso en los placeres [...] por una libre determinación, sólo por ellos mismos y no con la mira de ningún otro resultado, éste es verdaderamente incontinente» (Aristóteles, Ética a Nicómaco, pp. 290-291). 
A pesar de la reacción iracunda de Segismundo contra el que había sido su tutor durante el encierro, a quien por dos veces intenta matar, Clotaldo nunca deja de aconsejar a Segismundo:

$$
\begin{aligned}
& {[\ldots] \text { que seas }} \\
& \text { más apacible, si reinar deseas; } \\
& \text { y no, por verte ya de todos dueño, } \\
& \text { seas crüel, porque quizá es un sueño. }
\end{aligned}
$$

(vv. 1676-1679)

Pero aunque estas intervenciones de Clotaldo van marcando un cierto contrapunto a los presupuestos deterministas que imperan en las jornadas I y II, es a partir del final de la jornada II cuando empieza a entreverse una respuesta a las proposiciones de la predestinación y el siervo albedrío. Según el análisis propuesto, el motivo de estudio aquí es el sueño en cuanto símbolo perteneciente en la tradición cultural —mimesis I-, determinante en la configuración de la trama — mimesis II —y presente en la refiguración interpretativa —mimesis III-.

\section{LA COOPERACIÓN DEL LIBRE ALBEDRÍO A LA MOCIÓN DE LA GRACIA}

El examen de este símbolo nos lleva a sugerir que el cambio operado en Segismundo en la jornada III puede apuntar a la inspiración de la gracia a través del sueño, aunque sea de un modo implícito ${ }^{23}$. En efecto, a través de la gracia podría explicarse una conversión tan vertiginosa, puesto que pasa del libertinaje a la virtud en una sola jornada. Es cierto que, por una parte, el concepto teológico no aparece claramente mencionado, y que, por otra parte, tanto el género dramático como la época barroca tendían a concentrar en pocos versos intensísimas transformaciones psicológicas. Además, cabe recordar aquí el precedente literario de la conversión del protagonista en el cono-

23 «Segismundo despierta convencido de que su estancia en el palacio real fue sólo un sueño, pero ha conocido el desengaño del mundo y ha calibrado el valor de lo eterno. El príncipe de Polonia experimenta una especie de metamorfosis cristiana; el desengaño lo impulsa a una salvadora metanoia» (Andueza, 2001). 
cido episodio del Guzmán de Alfarache $e^{24}$; sin embargo, la posible influencia de la novela de Mateo Alemán presenta dos objeciones: en primer lugar, el sueño sigue a la reflexión del protagonista ${ }^{25}$, y en segundo lugar, la sinceridad de tal conversión es objeto de polémica por parte de la crítica $^{26}$.

En cuanto a la obra que nos ocupa, es indiscutible la importancia capital del sueño en la conversión de Segismundo y la radicalidad de su transformación. Pero junto al tópico literario el sueño destaca también como motivo bíblico, en cuanto medio del que Dios se sirve a menudo para revelar Su voluntad. Así, las continuas referencias al sueño podrían leerse desde una perspectiva teológica, como relacionadas con las inspiraciones divinas. De hecho, es el mismo protagonista quien atribuye al sueño una connotación trascendente, pues lo interpreta como el estadio previo al despertar a la vida eterna:

la experiencia me enseña que el hombre que vive sueña lo que es hasta despertar.

(vv. 2155-2157)

Por eso, cuando despierta de nuevo en su prisión en la jornada II, a la primera turbación sigue una cierta iluminación del entendimiento que le sugiere una interpretación espiritual del sueño. Es decir, aun cuando la realidad es ambigua, la salvación del alma exige obrar rectamente:

24 «Ya con las desventuras iba comenzando a ver la luz de los que siguen la virtud [...]. De donde vine a considerar y díjeme una noche a mí mismo: "¿Ves aquí, Guzmán, la cumbre del monte de las miserias, adonde te ha subido tu torpe sensualidad? Ya estás arriba y para dar un salto en lo profundo de los infiernos o para con facilidad, alzando el brazo, alcanzar el cielo. [...] Vuelve y mira que, aunque sea verdad haberte traído aquí tus culpas, pon esas penas en lugar que te sean de fruto"» (Alemán, Segunda parte de la vida de Guzmán de Alfarache, atalaya de la vida humana, II, III, 8).

25 «En este discurso y otros que nacieron dél, pasé gran rato de la noche, no con pocas lágrimas, con que me quedé dormido y, cuando recordé, halléme otro, no yo ni con aquel corazón viejo que antes» (Alemán, Segunda parte de la vida de Guzmán de Alfarache, atalaya de la vida humana, p. 334).

${ }^{26}$ Ver José María Micó, 1987; Michel Cavillac, 1993; y Benito Brancaforte, 1980. 


\begin{abstract}
Mas, sea verdad o sueño, obrar bien es lo que importa. Si fuere verdad, por serlo; si no, por ganar amigos para cuando despertemos.
\end{abstract}

(vv. 2423-2427)

Esta interpretación del protagonista va más allá del cierto consuelo psicológico que pretendía Basilio al adormecer a su hijo. Tampoco puede decirse que el comportamiento anterior de Segismundo anticipe esta reacción, ni basta para justificarlo en su experiencia de la Corte. En cambio, sí podría explicarla la moción divina a través del sueño. Desde este punto de vista, la salvación de Segismundo se produciría efectivamente a través de la gracia, pues Dios santifica sin la intervención del hombre pero no sin su consentimiento ${ }^{27}$. Por eso, la respuesta de la segunda parte de la obra es tanto más completa por cuanto no sólo revela el paso de la gracia por el alma de Segismundo a través del sueño, sino también porque muestra cómo el príncipe acepta esta gracia reflexionando a partir del sueño.

Mientras el movimiento divino había sido apenas sugerido a través del motivo barroco y bíblico del sueño, de modo que se reconoce más por sus frutos en el alma de Segismundo que por una mención explícita, la progresiva aceptación de la gracia aparece, en cambio, descrita con minuciosidad. Con maestría Calderón convierte las limitaciones espaciales del género dramático en intensificadores que le permiten retratar la ascesis espiritual del protagonista, mostrando sus dudas y vacilaciones en los apartes del diálogo. Esto le permite, por ejemplo, reflejar en una misma intervención del protagonista sus sentimientos encontrados respecto a la lealtad de Clotaldo:

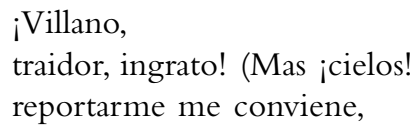

¡Villano,

traidor, ingrato! (Mas ¡cielos!

reportarme me conviene,

27 «La justificación del pecador es producida por Dios, que impulsa al hombre al estado de justicia. Pero [...] el impulso que Dios le comunica para conducirlo a la justicia no se produce sin el ejercicio del libre albedrío humano, sino que de tal manera infunde el don de la gracia justificante, que mueve a la vez el albedrío del hombre para que acepte la gracia» (Summa Theologiae, I, q. 113, a. 3). 
que aún no sé si estoy despierto.)
Clotaldo, vuestro valor
os envidio y agradezco.
Idos a servir al Rey,
que en el campo nos veremos.

(vv. 2410-2417)

En estos pocos versos se hace patente cómo el recuerdo del sueño — esto es, el movimiento de la gracia, según nuestra apuesta interpretativa - templa la ira de Segismundo cuando él mismo, voluntariamente, lo trae a la memoria.

Pero sus contradicciones interiores se traslucen especialmente durante su último encuentro con Rosaura, donde se hace evidente también el mayor esfuerzo de moderación. A lo largo de un extenso aparte, el espectador asiste a la lucha interna entre la fuerza de los sentidos que lo arrastra con el recuerdo del libertinaje pasado y la verdad conocida a través del sueño que le impone templanza. Segismundo se encuentra en una situación parecida a la vivida en la Corte, con la doncella a su merced

Rosaura está en mi poder, su hermosura el alma adora.

(vv. 2958-2959)

A la belleza de la dama se suma su vulnerabilidad todavía mayor, pues recurre al príncipe en demanda de auxilio. La oportunidad se presenta, por tanto, favorable:

Gocemos, pues, la ocasión;

el amor las leyes rompa

del valor y confianza

con que a mis plantas se postra.

(vv. 2960-2963)

Instigado por su deseo, Segismundo pretende hacer asentir a su razón utilizando el mismo argumento del sueño:

Esto es sueño; y pues lo es, soñemos dichas agora, 
que después serán pesares.

(vv. 2964-2966)

De inmediato, como si la gracia tocara de nuevo su entendimiento, el príncipe rectifica su elección:

Mas con mis razones propias vuelvo a convencerme a mí.

(vv. 2967-2968)

Si es sueño, si es vanagloria, ¿quién por vanagloria humana pierde una divina gloria?

(vv. 2969-2971)

Esta mención de la bienaventuranza parece indicar que Segismundo ha asimilado finalmente la enseñanza del sueño. Dicho de otro modo: el protagonista ha aceptado libremente la moción de la gracia, pues el desengaño de la realidad a través del sueño lo ha conducido al anhelo de la vida eterna:

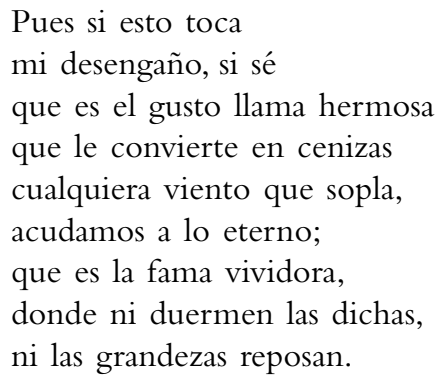

(vv. 2977-2985)

Los ecos manriqueños de esta "fama vividora» señalan a una comprensión profunda de su condición regia: como gobernante, la fama no es el fin de sus actos, sino el efecto de una conducta intachable en orden al bien de sus súbditos y de su alma. El príncipe demuestra haber comprendido esta lección al sobreponer el bien de Rosaura a su propio interés: 
Rosaura está sin honor;

más a un príncipe le toca

el dar honor que quitarle.

(vv. 2986-2988)

Tras el largo combate interior, el entendimiento asiente y llega el momento en que Segismundo debe ejercer la verdadera libertad sujetando su voluntad a la razón. Con este último esfuerzo por dominar su pasión termina el aparte:

Huyamos de la ocasión, que es muy fuerte.

(vv. 2992-2993)

Esta escena pone de manifiesto lo que la transformación de Segismundo conlleva: una regeneración interior que presupone la libertad de aceptar la gracia o desecharla. No sólo sus palabras sino también su actuación, que corrige cada acto de tiranía anterior, afirman el libre albedrío de Segismundo y desmienten la predestinación negativa del hado que pesaba sobre él.

Por tanto, así como el conflicto en torno al cumplimiento del hado da origen a la obra, esta misma cuestión debe darle término: el problema del sino fatal de Segismundo se resuelve en un desenlace circular perfecto. El discurso final del príncipe reproduce la alocución con la que su padre iniciaba la obra:

BASILIO Ya sabéis —estadme atentos,

$[\ldots]$

corte ilustre de Polonia

(vv. 600-602)

Segismundo Corte ilustre de Polonia, que de admiraciones tantas sois testigos, atended

(vv. 3158-3160)

BASILIO en papel de diamante, en cuadernos de zafiros, escribe con líneas de oro, en caracteres distintos, 
el cielo nuestros sucesos
ya adversos o ya benignos.

(vv. 634-639)

Segismundo Lo que está determinado

del cielo, y en azul tabla

Dios con el dedo escribió,

de quien son cifras y estampas

tantos papeles azules

que adornan letras doradas

(vv. 3162-3167)

Ambos están de acuerdo en que estos signos de los cielos

nunca miente[n], nunca engaña[n]

(v. 3168)

Es decir, tanto Basilio como Segismundo aseveran la certeza de la predestinación; no obstante, difieren en el modo de afrontarla. En este punto, resulta muy significativa la inversión de la causalidad: mientras que para el rey la fiereza de su hijo había sido pronosticada por los astros y sólo podía ser aplacada mediante el encierro, Segismundo proclama que su brutalidad no fue causa sino consecuencia del trato recibido,

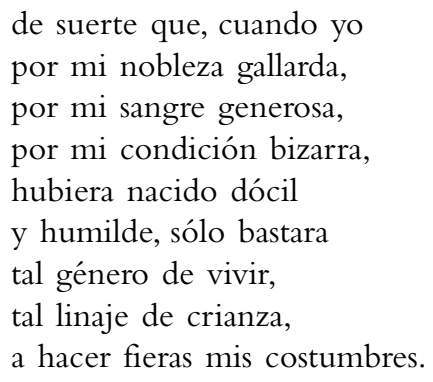

(vv. 3176-3184)

Y continúa afirmando que sólo la adquisición de la virtud puede regir aquella alma asilvestrada, devolviéndole la condición verdaderamente humana, pues 
quien vencer aguarda

a su fortuna, ha de ser

con prudencia y con templanza.

(vv. 3217-3219)

Estas palabras vienen a refrendar las actuaciones del príncipe tras su segundo despertar: con templanza ha vencido la ira ante Clotaldo y la lujuria ante Rosaura, y con prudencia ha moderado su arrogancia a la cabeza del ejército. De este modo ha desmentido no sólo su comportamiento anterior en la Corte sino sobre todo la profecía que más inquieta a Basilio y que el mismo Segismundo pone como ejemplo final de su invectiva contra la predestinación, puesto que verdaderamente ha llegado a ver

rendido a mis pies a un padre, y atropellado a un monarca.

(vv. 3234-3235)

Por eso, el príncipe demuestra ser verdaderamente virtuoso cuando «emplea su virtud para otro ${ }^{28}$ y se dirige inesperadamente a su padre:

Señor, levanta,
dame tu mano; que ya
que el cielo te desengaña
de que has errado en el modo
de vencerle, humilde aguarda
mi cuello a que tú te vengues;
rendido estoy a tus plantas.

(vv. 3241-3247)

El conflicto dramático ha sido resuelto, la refutación teológica se ha completado: Segismundo ha triunfado sobre las predicciones. De palabra y de obra Segismundo apunta la solución: para vencer el hado no basta la sujeción física sino la sujeción moral, no el dominio de otro mediante la fuerza sino el dominio de uno mismo por medio de la virtud. De este modo, el príncipe no adquiere la verdadera libertad

${ }^{28}$ Aristóteles, Ética a Nicómaco, p. 204. 
cuando es desencadenado y llevado a la Corte entre lujos y honores, sino cuando con la ayuda de la gracia entra en sí y alcanza el señorío de sus pasiones. Por eso, el Segismundo vencedor, aclamado por todos, concluye:

\author{
Pues que ya vencer aguarda \\ mi valor grandes vitorias, \\ hoy ha de ser la más alta \\ vencerme a mí.
}

(vv. 3255-3258)

El mayor triunfo no consiste en la gloria humana, perecedera y vana como el sueño, sino en la victoria sobre sí mismo. Dicho de otro modo, la verdadera libertad se conquista por medio de la virtud, que se adquiere y se manifiesta en el obrar ${ }^{29}$.

\title{
Mimesis II y mimesis III
}

Así se da término a la obra y a la revisión del argumento como configuración de mimesis I, esto es, como reelaboración dramática de la polémica teológica en torno a la libertad, cuestión candente en la época de Calderón. La representación de cada postura — predestinación negativa, libre albedrío movido por la gracia - se manifiesta en la actuación de los personajes, según el precepto de la Poética, retomado por Ricoeur, que da primacía a la acción sobre todas las partes constitutivas de la tragedia ${ }^{30}$ : el encierro, el libertinaje de Segismundo y su posterior conversión, las reacciones de quienes lo rodean. Todos estos actos construyen la trama —mimesis II —y son además los elementos que suscitan temor y compasión, es decir, aquellos que provocan la catarsis. El análisis se adentra de este modo en mimesis III, que contempla la refiguración de la obra a través del receptor. Además de

${ }^{29}$ Uno se hace virtuoso practicando actos de virtud «porque las virtudes sólo se conquistan mediante la constante repetición de actos de justicia, de templanza, etc.» (Aristóteles, Ética a Nicómaco, p. 106).

30 «El más importante de estos elementos es la estructuración de los hechos, porque la tragedia es imitación, no de personas, sino de una acción y de una vida, y la felicidad y la infelicidad están en la acción, y el fin es una acción, no una cualidad» (1450a16-17). 
la catarsis, que se tratará al final, la relación de mimesis II con mimesis III abarca también la posible influencia posterior de La vida es sueño, por cuanto «lo que el lector recibe no sólo es el sentido de la obra, sino también, por medio de éste, su referencia: [...] el mundo y su temporalidad $»^{31}$. Cabe examinar ahora, por tanto, si la obra se limita a su circunscripción histórica y cultural o la trasciende para dialogar con la época contemporánea.

Aunque el contexto es distinto, el determinismo que subyace en la predestinación protestante es en esencia similar al determinismo en que se fundamenta, por ejemplo, la teoría psicoanalítica. La posibilidad de hallar una referencia propia de mimesis III en el psicoanálisis parte de la figura del padre, pieza fundamental en el conflicto dramático y en la propuesta freudiana. A este elemento se añade otra clave de la trama: la importancia del sueño, común a la obra y al psicoanálisis. Ambos puntos se expondrán a continuación como fundamentos de mimesis II que hallan su eco en cierto determinismo contemporáneo, ámbito de mimesis III.

\section{LA FIGURA DEL PADRE}

En el conflicto dramático de La vida es sueño se puede señalar cierta analogía con el "complejo nuclear de toda neurosis»" ${ }^{32}$ según Freud. Así como el encierro es consecuencia de la predicción parricida, también la represión moral del Superyó intenta ahogar el deseo inconsciente de asesinar al padre. No obstante, el determinismo que subyace en el complejo de Edipo es negado en la obra calderoniana incluso antes de la conversión del príncipe. En efecto, cuando en su primera estancia en la Corte Segismundo declara su intención de matar a Basilio, habla de forma consciente y fundándose en un argumento, si no racional, al menos lógico: el asesinato del padre sería una venganza por el trato recibido.

\section{Acciones vanas}

querer que tenga yo respeto a canas;

pues aun ésas [de Basilio] podría

31 Ricoeur, 1995, p. 150.

32 Echavarría, 2010, p. 26. 
ser que viese a mis plantas algún día, porque aún no estoy vengado del modo injusto con que me has criado.

(vv. 1714-1719)

Es decir, el odio del príncipe no es una manifestación psíquica de un fenómeno biológico ${ }^{33}$, sino un movimiento del alma, desordenado por cuanto se opone a la caridad ${ }^{34}$, pero voluntario al fin y al cabo.

La figura del padre resulta clave, por tanto, para intentar demostrar el libre albedrío del protagonista frente a interpretaciones freudianas. Precisamente porque el conflicto paterno-filial es explícito en la obra, la diferencia entre la teoría de Freud y la propuesta de Calderón puede verse con mayor claridad a partir de las semejanzas. Si para el psicoanálisis el padre es quien encarna los ideales y prohibiciones culturales que esclavizan al Yo ${ }^{35}$, en La vida es sueño la represión paterna se hace todavía más evidente a través de la prisión. Toda la carga negativa del padre como autoridad opresora se personifica en el rey Basilio, figura hostil incluso contra la naturaleza misma de la paternidad, tal como le reprocha Segismundo:

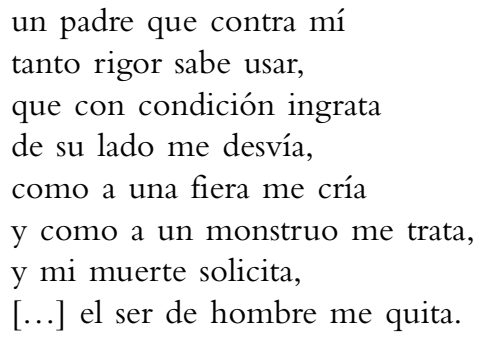

(vv. 1478-1487)

Ante este conflicto dramático de tintes freudianos, destaca la actuación libre de Segismundo. Frente a la figura indudablemente negativa de su padre, el príncipe da muestras de una libertad que parece desmentir la apariencia del complejo de Edipo inicial. Además de ser plenamente consciente del odio que siente hacia su progenitor, el

${ }^{33}$ Ver Echavarría, 2010, p. 21.

34 Summa Theologiae, II, q. 158, a. 3.

${ }^{35}$ Ver Echavarría, 2010, pp. 28-29. 
protagonista escoge de forma voluntaria su actitud: en primer lugar, la ira; pero al final, el perdón. He aquí la manifestación plena de su libertad frente al mecanicismo psíquico ${ }^{36}$ de Freud: Segismundo es capaz de superar su complejo de Edipo particular al elegir reconciliarse con el padre a pesar de las pulsiones de muerte que lo abocaban al odio. Segismundo se hace verdaderamente libre al perdonar y someterse a su padre, mientras que un paciente psicoanalizado debe tomar conciencia de la muerte del padre para librarse de sus neurosis ${ }^{37}$.

Frente a una situación semejante, La vida es sueño y el psicoanálisis presentan soluciones opuestas. Si partiendo de estos efectos retrocedemos hacia los síntomas antes de llegar a las causas, notaremos otra coincidencia: el sueño. Tanto en la obra como en la terapia el sueño es un camino, aunque de nuevo sigue direcciones inversas.

\section{El CAMINO DeL SUEÑO}

Sería redundante insistir de nuevo en la centralidad del sueño en la obra de Calderón. Por su parte, es bien conocida la importancia del sueño en el psicoanálisis como medio por el que el paciente manifiesta sin censura sus deseos inconscientes. Si aplicamos esta afirmación a La vida es sueño, observamos que algo parecido ocurre en la primera experiencia de Segismundo en la Corte. Al despertar en palacio se encuentra en una situación fronteriza entre el sueño y la realidad, cuya misma indefinición implica para él la ausencia de límites. Este estado casi irreal dispone su ánimo para dejarse arrastrar por las pasiones irracionales

Dejarme quiero servir $\mathrm{y}$ venga lo que viniere.

(vv. 1246-1247)

${ }^{36}$ Ver Echavarría, 2010, p. 22.

37 «El paciente pone al psicoanalista en el lugar pedagógico del padre y lo considera inconscientemente como un representante de Dios y de su ley. Pero [...] el psicoanalista debe «correrse de ese lugar» de autoridad en que lo pone el paciente y dejarlo vacío [...] para que la persona se dé cuenta de que Dios ha muerto, y de que en su lugar está el vacío, la muerte misma, que es la fuente de la angustia». Echavarría, 2010 , p. 35. 
En cierto modo, la posición intencionadamente confusa en que lo ha colocado Basilio hace aflorar los instintos del príncipe. En efecto, cabe recordar que el rey lo adormece mediante una bebida narcótica para que revele su condición natural. Utilizando el lenguaje psicoanalítico, podríamos decir que el padre libera las pulsiones del hijo a través del sueño.

Sin embargo, no hay que olvidar que el protagonista es consciente en todo momento de que está despierto: esto lo convierte en responsable de sus actos, al contrario de lo que ocurre en la terapia psicoanalítica, donde no se juzga la responsabilidad de los actos, sino su origen. Esta diferencia entre el paciente del psicoanálisis - cuyos sueños revelan su Ello- y el protagonista de la obra - que en un sueño aparente manifiesta su Yo- deriva de una concepción divergente de la libertad humana. La terapia psicoanalítica parte del mecanicismo para interpretar que lo inconsciente es involuntario porque no radica en la voluntad libre, sino que tiene un origen fisico que elimina toda espontaneidad ${ }^{38}$. Frente a esta negación, el drama barroco parece oponer una exaltación de la voluntad: la actuación desenfrenada de Segismundo en palacio vendría a demostrar que el hombre escoge libremente incluso su mal:

las pasiones que la razón no guía no pertenecen menos a la naturaleza humana, lo mismo que las acciones inspiradas al hombre por la cólera y el deseo. Concluyamos, pues, que sería verdaderamente un absurdo declarar que estas cosas no están sometidas a nuestra volun$\operatorname{tad}^{39}$.

Podríamos encontrar aún otro ejemplo de este diálogo secular con Freud: existe, en efecto, un sueño real de Segismundo en la obra que es escuchado y, en cierto modo, analizado por Clotaldo. Cuando despierta el paciente-Segismundo, a petición del consejero-Clotaldo declara lo que ha soñado y éste interviene para ofrecer una interpretación de la causa del sueño

38 «Le pulsioni, poi, non sarebbero delle funzioni autonome, ma solo l'espressione psichica di stimoli somatici, a loro volta strettamente collegati a processi fisiologici: «Se ora ci rivolgiamo a considerare la vita psichica dal punto di vista biologico, la 'pulsione' ci appare come un concetto limite tra lo psichico e il somatico, come il rappresentante psichico degli stimoli che traggono origine dall'interno del corpo e pervengono alla psiche». Freud, Pulsioni e loro destini, citado por Pavesi, 1991.

39 Aristóteles, Ética a Nicómaco, pp. 126-130. 


\section{Como habíamos hablado} de aquella águila, dormido, tu sueño imperios han sido.

(vv. 2140-2142)

No obstante, pese a esta analogía entre la posición del anciano consejero y la función del psicoanalista, Clotaldo se aleja definitivamente de la concepción freudiana cuando utiliza el sueño con un fin educativo, al avisar al príncipe de

que aun en sueños no se pierde el hacer bien.

(vv. 2146-2147)

Tras esta sentencia, el consejero desaparece y Segismundo pronuncia el monólogo que revela el inicio de su conversión interior:
Es verdad; pues reprimamos esta fiera condición, esta furia, esta ambición por si alguna vez soñamos.

(vv. 2148-2151)

El sueño consituye, pues, una verdadera toma de conciencia para el protagonista, tal como ocurre en el psicoanálisis. En ambos casos se privilegia el sueño como medio, pero en modo radicalmente opuesto: usado en la terapia, hace aflorar los complejos reprimidos; utilizado en la obra, mueve a reprimir las pasiones desordenadas. Como si La vida es sueño se anticipara a la práctica del psicoanálisis, el sueño aparece como el lugar idóneo para la manifestación del conflicto y como vía regia para llegar al origen del comportamiento. Es en la raíz donde se encuentra la divergencia: el sueño revela el Yo sometido al Ello o el Ello sometido al Yo. Dicho de otro modo, las pulsiones dictan la subordinación a los instintos, mientras la educación de la virtud salvaguarda y hace posible la libertad. 


\section{CATARSIS}

A modo de conclusión, conviene distinguir el concepto de catarsis dentro del ámbito de mimesis III que se ha desarrollado en el punto anterior. Puesto que se trata del efecto producido en el espectador o lector — mimesis III- a partir de la disposición de los hechos - mimesis $\mathrm{II}^{40}$ —, determinados en cierto modo por el contexto - mimesis I-, cabe esperar un análisis global de los elementos clave de la trama. En efecto, las acciones que configuran el argumento - recordemos aquí la primacía de la acción sobre los caracteres expuesta en la Poética41 - sintetizan a la vez el movimento de la obra y su profundidad temática: encadenamiento y liberación. Estas dos situaciones marcan la evolución del protagonista y, sobre todo, permiten al autor construir intensísimos momentos dramáticos, a la vez que encarnan ciertas enseñanzas morales. De nuevo cabe recordar que mimesis III se ocupa de la capacidad referencial de la obra implícita en la intención del autor ${ }^{42}$, por lo que la conclusión se centrará en el carácter simbólico de las actuaciones de los personajes.

Resulta significativo advertir que Segismundo es liberado dos veces a lo largo de la obra, como si Calderón quisiera proponer dos concepciones distintas de libertad. Ambas parten del mismo presupuesto: las pasiones desordenadas pueden esclavizar al hombre subyugando su voluntad y su razón. El predominio de los instintos se identifica con la condición animal y convierte a Segismundo en

un hombre de las fieras

y una fiera de los hombres.

(vv. 211-212)

40 «La catarsis es una purificación —o mejor [...] una purgación que tiene lugar en el espectador. [...] Pero esta alquimia subjetiva se construye también en la obra por la actividad mimética. [...] la dialéctica de lo interior y de lo exterior alcanza su punto culminante en la catarsis: el espectador lo experimenta, pero se construye en la obra» (Ricoeur, 1995, p. 111).

41 «Los personajes son tales o cuales según el carácter; pero, según las acciones, son felices o lo contrario. Así, pues, no actúan para imitar los caracteres, sino que revisten los caracteres a causa de las acciones» (1450a22).

${ }^{42}$ Ver Ricoeur, 1995, p. 150. 
La fiereza del príncipe es, por tanto, la causa común de sus dos encarcelamientos: para prevenirla, primero; para castigarla, después. A cada encierro sigue una liberación, y cada una parece encarnar una reacción posible ante el poder de las pasiones: dejarse arrastrar por ellas o luchar por vencerlas. La primera salida de Segismundo de la prisión, inconsciente e involuntaria, correspondería a la satisfacción de los impulsos, pero termina de nuevo en la cárcel; la segunda salida de la torre, consciente y voluntaria, representa el dominio de los impulsos y la victoria final del príncipe sobre sí mismo.

En la primera liberación, el protagonista proclama la primacía de los instintos ${ }^{44}$ sobre la voluntad y la razón cuando se consagra a la satisfacción de sus apetitos irascible y concupiscible, particularmente la ira y la lujuria. Tal desorden de las pasiones impide a Segismundo ser verdaderamente libre, puesto que lo esclaviza a los apetitos inferiores. Pese a la apariencia de libertad, no le es posible escoger libremente un fin, porque su único objeto es la continua satisfacción de sus instintos. Calderón parece querer enfatizar esta esclavitud moral con las cadenas físicas, encarcelando de nuevo al protagonista: el fracaso de la experiencia de libertinaje se traduce en el retorno a la prisión inicial. Este círculo que se cierra podría representar la experiencia de Segismundo como una concatenación de factores que condicionan absolutamente su comportamiento. El predominio de las pasiones sería manifestación de su verdadera condición, reprimida mediante el encierro.

Tal interpretación es refutada por la segunda liberación de Segismundo: el príncipe demuestra en su segunda salida de la torre que es capaz de romper el encadenamiento psíquico y moral que lo inmovilizaba. Con la ayuda de la gracia, según la hipótesis de este trabajo, el príncipe alcanza la verdadera libertad restituyendo el orden natural por el que los apetitos inferiores se subordinan a los apetitos superiores ${ }^{45}$.

Su primera elección libre, guiada por la razón, será precisamente abandonar la prisión para ponerse al mando del ejército rebelde. Segismundo acepta el poder que le ofrecen sólo tras meditar sobre la

44 En La vida es sueño no aparece en ningún momento el término instinto, pero la noción de fiera adopta un significado análogo.

45 «Pertenece a la perfección del bien moral o humano que las pasiones del alma sean reguladas por la razón» (Summa Theologiae, I, q. 24, a. 3). 
situación que se le presenta, advertido por la experiencia pasada,

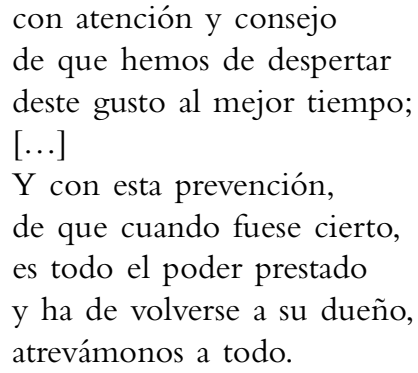

(vv. 2361-2372)

Así empieza a cumplir su intención de reprimir «esta fiera condición» (v. 2149), pues la pasión irascible que sin duda predomina en su naturaleza es por fin imperada por la razón. Los instintos ya no lo esclavizan porque los ha sometido a un fin: la preocupación por la vida eterna, "por ganar amigos / para cuando despertemos» (vv. 2426-2427). Este fin aparece más nítido al tiempo que la gracia ilumina su razón, hasta que lo mueve a rechazar la tentación concupiscible frente a Rosaura por no perder la gloria eterna. Con aquel «acudamos a lo eterno" (v. 2982) podría decirse que el apetito del bien divino ha liberado la voluntad del príncipe y, por tanto, lo ha hecho verdaderamente libre, puesto que conociendo su fin puede escoger libremente los medios ${ }^{46}$.

Así pues, los apetitos sensitivos desordenados en la primera liberación son sometidos al apetito racional en la segunda salida de la torre, de tal modo que el protagonista pasa de la esclavitud de los instintos a la libertad fundamentada en la virtud. En efecto, si en la jornada II la ira y la lujuria predominaban en su actuación en la corte, en la jornada III la fortaleza y la templanza guían su actuación en el campo de batalla. Precisamente allí se libra la lucha final de Segismundo por vencer sus pasiones, como si Calderon quisiera trasladar al terreno exterior el combate interior que tiene lugar en el alma de

${ }^{46}$ Voluntad y libre albedrío son la misma potencia, aunque se distinguen en el objeto: «la voluntad tiene por objeto el fin, deseado por sí mismo», mientras que la facultad electiva tiene por objeto «los medios que llevan al fin». Pero es «una misma potencia la que elige y la que quiere» (ver Summa Theologiae, I, q. 83, a. 4). 
Segismundo. Dos actos coronan su victoria sobre sí mismo: el sometimiento ante su padre, sabiendo que merece la muerte como traidor al rey, y la renuncia a Rosaura, entregada en matrimonio a Astolfo para reparar su honor. Estos dos actos virtuosos reparan las ofensas anteriores y ejercitan las virtudes adquiridas. A través del sueño actúa la gracia revelando el fin último que ordena su voluntad y le permite escoger libremente los medios: por medio de las virtudes conquista la verdadera libertad, que se manifiesta en la victoria sobre sí mismo.

El análisis de este desarrollo dramático a través de la «triple mimesis» permite acceder al carácter simbólico de esta enseñanza. La universalidad de la obra reside en su capacidad catártica y su potencial comunicativo, suscitados a partir de la representación de la libertad en toda su intensidad dramática. Mimesis y catarsis componen la voz de La vida es sueño en su diálogo intemporal. 


\section{Bibliografía}

Alemán, M., Segunda parte de la vida de Guzmán de Alfarache, atalaya de la vida humana, Madrid, Tiempo, 2004.

Antonucci, F., «Introducción» a La vida es sueño, Barcelona, Crítica, 2008.

Andueza, M., «Libertad/destino en La vida es sueño de Calderón de la Barca», en 400 años de Calderón, coord. A. González, México D. F., Universidad Nacional Autónoma de México, 2001, pp. 139-154.

Aquino, T., Summa Theologiae, ed. H. Mac Cabe, London, Eyre \& Spottiswoode, 1964.

Aristóteles, Ética a Nicómaco, Madrid, Espasa Calpe, 2002.

- Poética, ed. V. García Yebra, Madrid, Gredos, 1974.

Brancaforte, B., Guzmán de Alfarache: ¿conversión o proceso de degradación?, Madison, Hispanic Seminary of Medieval Studies, 1980.

Calderón de la Barca, P., la vida es sueño, ed. F. Antonucci, Barcelona, Crítica, 2008.

Calvino, J., Institución de la religión cristiana.

en <http://www.iglesiareformada.com/Calvino_Institucion_1_1.html>.

Cavillac, M. «Les trois conversions de Guzmán de Alfarache (regard sur la critique récente)», Bulletin Hispanique, 95, 1993, pp. 149-201.

Denzinger, H., Enchiridion Symbolorum, Barcelona, Herder, 2000.

Echavarría, M., Corrientes de psicología contemporánea, Barcelona, Scire, 2010.

Freud, S., «Cinco conferencias sobre el psicoanálisis», Obras completas, vol. 11, III, Madrid, Amorrortu, 1979.

- Pulsioni e loro destini, citado por Pavesi, E., "Appetitus in S. Tommasso e pulsione in Sigmund Freud», Studi Tomistici, 42, Padova, Libreria Editrice Vaticana, 1991, pp. 353-361.

Lutero, M., De servo arbitrio.

en <http://www.iglesiareformada.com/Luther_Servo_Arbitrio_1.html>.

Menéndez Pelayo, M., "Calderón y su teatro», en Estudios y discursos de crítica histórica y literaria, Santander, CSIC, 1941, vol. III.

Micó, J. M., «Introducción» a Guzmán de Alfarache, Madrid, Cátedra, 1987.

Riquer, M., «Introducción» a La vida es sueño, Barcelona, Juventud, 2005.

Riguer, M. y J. M. Valverde, Historia de la literatura universal, Madrid, Gredos, 2010, vol. I.

Ricoeur, P., Tiempo y Narración. Configuración del tiempo en el relato histórico, trad. A. Neira, México, Siglo xxi, 1995, vol. I.

Rodríguez Cuadros, E., "La vida es sueño»: obra paradigmática, Alicante, Biblioteca Virtual Miguel de Cervantes, 2007.

Sánchez Palencia, A., "Catarsis en la Poética de Aristóteles», Anales del Seminario de Historia de la Filosofía, 13, 1996, pp. 127-148. 